\title{
Impact of heavy metal bioaccumulation on antioxidant activities and DNA profile in two earthworm species and freshwater prawn from Ogun River
}

\author{
G.A. Dedeke ${ }^{\text {a }}$, P.O. Iwuchukwu ${ }^{\text {b,* }}$, A.A. Aladesida ${ }^{\text {b }}$, T.A. Afolabi ${ }^{\text {c }}$, I.O. Ayanda ${ }^{\text {a }}$ \\ a Department of Biological Sciences, Covenant University, Ota, Nigeria \\ ${ }^{\mathrm{b}}$ Department of Pure and Applied Zoology, Federal University of Agriculture, Abeokuta, Nigeria \\ c Department of Chemistry, Federal University of Agriculture, Abeokuta, Nigeria
}

\section{H I G H L I G H T S}

- Test organisms accumulated varying concentration of heavy metals in their tissues.

- Accumulated metals resulted to the low activities of most antioxidants in the test organisms.

- Earthworm indicated mutation due to heavy metals. However, freshwater prawns showed no variations.

\section{A R T I C L E I N F O}

\section{Article history:}

Received 9 July 2017

Received in revised form 3 December 2017

Accepted 4 December 2017

Available online 27 December 2017

Editor: Daniel Wunderlin

\section{Keywords:}

Heavy metals

Freshwater prawn

Earthworm

DNA-profile

Dendrogram

Genetic variability

Ogun River
G R A P H I C A L A B S T R A C T

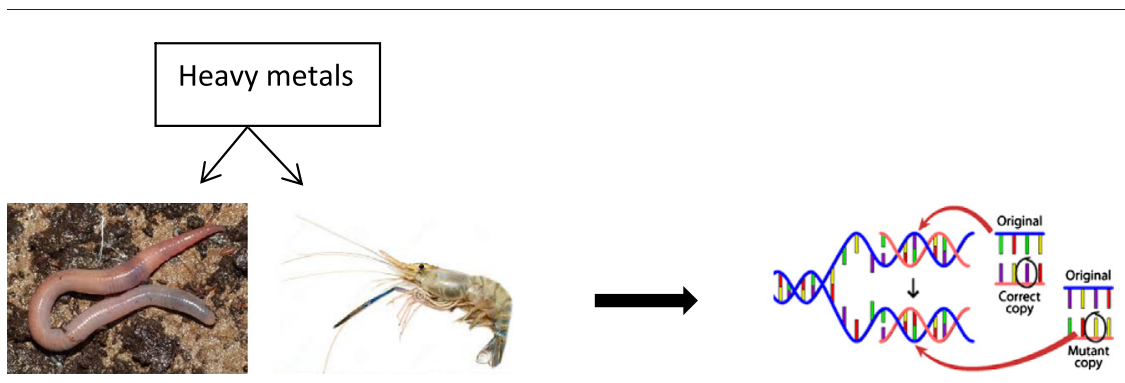

\begin{abstract}
A B S T R A C T
The use of freshwater invertebrates as bioindicator of heavy metal pollution is an important tool for environmental biomonitoring. This study investigated antioxidant activities and DNA profile in two limicolous earthworms (Alma millsoni and Libyodrilus violaceus) and freshwater prawns (Macrobrachium vollenhovenii) at selected points of Ogun River, Abeokuta. Heavy metal concentrations and DNA profile in the earthworms and prawn tissues were measured using standard procedures. Zn concentration was higher than other heavy metals in A. millsoni (685.83 $\pm 114.42 \mathrm{mg} / \mathrm{kg})$, L. violaceus (1913.3 $\pm 1098.7 \mathrm{mg} / \mathrm{kg}$ ) and M. vollenhovenii $(134.7 \pm 13.61 \mathrm{mg} / \mathrm{kg})$. Superoxide dismutase activity ranged from $62.44 \pm 7.16-79.82 \pm 11.18 \mathrm{U} / \mathrm{g}$ tissues, $60.26 \pm 11.18-71.07 \pm 7.54 \mathrm{U} / \mathrm{g}$ tissues and $74.07 \pm 16.69-87.79 \pm 8.50 \mathrm{U} / \mathrm{g}$ tissues in A. millsoni, L. violaceus and M. vollenhovenii respectively. RAPDPCR revealed varying DNA profile among the earthworms samples; the UPGMA dendrogram formed two distinct clusters at genetic similarity coefficient of $0.15-0.2$ with one cluster consisting of Alma millsoni and Libyodrilus violaceus from Sokori, Enugada and Iberekodo sampling points and the second cluster forming two distinct sub-clusters comprising Arakanga and Ago-ika's L. violaceus in one and A. millsoni in the other. High genetic variability was recorded among the earthworm species while the freshwater prawn showed no variability. Antioxidant activities and genetic variability in earthworms could serve as biomarkers of heavy metal pollution in freshwater environment.
\end{abstract}

(c) 2017 Elsevier B.V. All rights reserved.

\footnotetext{
* Corresponding author.

E-mail addresses: gabriel.dedeke@covenantuniversity.edu.ng (G.A. Dedeke), princewill.chukwu@gmail.com (P.O. Iwuchukwu), aladesidaaa@funaab.edu.ng (A.A. Aladesida), opeyemi.ayanda@covenantuniversity.edu.ng (I.O. Ayanda).
}

\section{Introduction}

Heavy metals coming majorly from human activities (urbanization and industrialization) are considered major contaminants of freshwater (Ubwa et al., 2013). Heavy metals such as $\mathrm{Cu}$, Fe and $\mathrm{Zn}$ are regarded as 
essential metals, because of their biological role in respiration, cell growth, protection and production of enzymes but when accumulated at higher concentrations, they can be toxic. On the other hand, heavy metals such as $\mathrm{Cd}, \mathrm{Hg}$ and As are not needed even in a minute quantity.

Metal accumulation in living system is often associated with various deleterious physiological effects such as low cast production by earthworms (Dittbrenner et al., 2010), impaired metabolic rate and energy depletion (Fisker et al., 2011), histopathological damage (Tarasub et al., 2011), ineffective burrowing activity (Pelosi et al., 2013), abnormal behavioural activities (Mariappan and Karuppasamy, 2014) and gonad maturation (Peranandam et al., 2014). The often ionic nature of these metals enables them to penetrate body surfaces and phospholipids of cell membranes, hence causing harm to the cell by producing radicals cumulatively called reactive oxygen species (ROS) such as perhydroxl radical $\left(\mathrm{HO}_{2}\right)$, hydroxyl radical $(\bullet \mathrm{OH})$ (Pratviel, 2012). These radicals results to imbalance between pro-oxidants and oxidants otherwise known as oxidative stress (Metcalfe and Alfonso-Alvarez, 2010). Also, influx of metals can result to the degradation of macromolecules such as lipids, protein and DNA (Joseph and Kafilat, 2012) thus leading to deleterious conditions such as genotoxicity and lipid peroxidation (Li et al., 2011).

Many freshwater macro-invertebrates respond to heavy metals pollution either morphologically, behaviorally or physiologically (Pablo et al., 2013), hence lowering the risk of the resulting negative effects. The responses by these groups of animals to heavy metal pollution could be exploited as early warning signals and could serve as powerful tools for assessing anthropogenic influence on freshwater environment. The antioxidant defense system readily eliminates any form of toxic effect or repair any form of damage caused by the ROS. Antioxidants such as superoxide dismutase (SOD), peroxidase, glutathione-S-transferase and glutathione are produced to reduce the destructive effects of ROS in organisms (Azqueta et al., 2009). Superoxide dismutase is one of the major antioxidants produced to counter superoxide anion by dismutation, GST detoxify ROS by conjugating with these substances, hence bringing to a halt the damage of ROS (Otitoloju and Olagoke, 2011).

Freshwater macro-invertebrates such as prawns and limicolous earthworms, which thrive successfully in the freshwater environment (Marioghae, 1990; Owa et al., 2010), occupy an important position in the food chain feeding on detritus and still a good recipe for other higher organisms. Studies have documented heavy metal bioaccumulation in freshwater prawn (Omoigberale and Ikponmwosa-Eweka, 2010; Manosathiyadevan et al., 2013) and limicolous earthworm such as Alma millsoni and Libyodrilus violaceus (Ebenezer et al., 2013), hence they are good biomonitoring agents for heavy metal pollution.

DNA damage caused by heavy metal pollution has been measured by several authors using RAPD-PCR (Ilhan et al., 2016; Kumar et al., 2015 and El Assal et al., 2014). The method is less expensive, yet very sensitive to identify DNA damage. For the DNA damage, we hypothesized to detect genetic mutation in sampled population, which might have been caused by heavy metal bioaccumulation resulting from the exposure of the population to these pollutants.

The objective of this study is to measure the effects of heavy metal bioaccumulation on antioxidant activities and DNA profile in two limicolous earthworms (Alma millsoni and Libyodrilus violaceus) and freshwater prawns (Macrobrachium vollenhovenii) collected from Ogun River, Abeokuta.

\section{Materials and methods}

Natural occurring specimen of limicolous earthworms and freshwater prawns were collected at different five sampling sites (A-Arakanga, B-Iberekodo, C-Ago-Ika, D-Sokori, E-Enugada) along Ogun River shown in Fig. 1 with their respective co-ordinates. Adult limicolous earthworms with well-developed clitella were collected at a depth of $0-2.0 \mathrm{~cm}$ in soil particles containing high humus along the bank of the river using the procedure of Owa (1992). Freshwater prawn samples were baited and trapped at the various sites in fishing baskets. Prawns were transported in ice-chest to the laboratory for further analysis, while, earthworm samples were transferred to the laboratory in well labeled clean polyethene bags.

\subsection{Identification of earthworm and prawn samples}

The earthworms were identified and described by an Animal Taxonomist in the Department Pure and Applied Zoology of the Federal University of Agriculture, Abeokuta while the prawn identification was done using Marioghae (1990) as a guide.

\subsection{Determination of heavy metal analysis in the water and tissue}

Frozen prawns were thawed partially at room temperature before opening. Shell and soft tissues were carefully separated from each prawn sample. Both parts of the samples were dried in the oven at $10{ }^{\circ} \mathrm{C}$ for $24 \mathrm{~h}$ to obtain a constant dry weight (dw). Earthworm samples were separated based on its species in well labeled petri-dishes after which they were oven dried at $60{ }^{\circ} \mathrm{C}$ for $24 \mathrm{~h}$. The dried samples were pulverized into powdery form. $1 \mathrm{~g}$ each of the dried powdered samples were digested by heating with $21 \mathrm{~mL}$ of concentrated nitric acid and $7 \mathrm{~mL}$ of concentrated hydrochloric acid according to the standard methods of the Association Of Analytical Chemist (AOAC, 2000). Digested sample were diluted with little amount of distilled deionized water. The solution was filtered using a Whatman No 1 filter paper. Heavy metal concentrations were determined using atomic absorption spectrophotometry.

\subsection{Antioxidants assays}

$10 \%$ homogenate tissue sample was prepared in ice-cold homogenization buffer (125 mM sucrose, $125 \mathrm{mM}$ mannitol, $1 \mathrm{mM}$ EGTA and 5 mM HEPES) ( $\mathrm{pH} 7.20 .25 \mathrm{M}$ ) with 15 strokes in a Teflon pestle homogenizer centrifuged at $3000 \mathrm{rpm}$ for $15 \mathrm{~min}$ at $4{ }^{\circ} \mathrm{C}$. The supernatant was kept at $-20{ }^{\circ} \mathrm{C}$ until analysis.

Glutathione-S-transferase activity determined according to the method of Habig et al. (1974). Two test tubes marked blank (B) and test $(\mathrm{T})$ were arranged in a test tube rack. Potassium phosphate buffer $(1.0 \mathrm{~mL}), 50 \mu \mathrm{L}$ of glutathione and $50 \mu \mathrm{L}$ of CDNB were pipeted into each of the tubes. Erythrocyte $(50 \mu \mathrm{L})$ was added to the mixture in the tube marked T while $50 \mu \mathrm{L}$ of buffer was added to the mixture in the tube marked B. They were mixed by inversion and the increase in absorbance was recorded for $5 \mathrm{~min}$. The difference between the initial and final absorbance and average absorbance difference was calculated $(\Delta \mathrm{A} 340 / \mathrm{min})$. GST activity was calculated as

Units $/ \mathrm{mL}$ enzyme $=\frac{(\Delta \mathrm{A} 340 \mathrm{~nm} / \mathrm{minTest}-\Delta \mathrm{A} 340 \mathrm{~nm} / \mathrm{minBlank})(1.15)(\mathrm{df})}{0.05 \times 9.6}$

where $1.15=$ Total volume (in milliliters) of assay

$\mathrm{df}=$ Dilution factor

$9.6=$ Millimolar extinction coefficient of Glutathione-1-Chloro-2,4-

Dinitrobenzene conjugate at $340 \mathrm{~nm}$

$0.05=$ Volume (in milliliter) of enzyme used

\subsection{Determination of superoxide dismutase (SOD)}

Superoxide dismutase activity was determined according to the method of Marklund and Marklund (1974). Two test tubes marked blank (B) and test (T) were arranged in a test tube rack. Potassium phosphate buffer $(100 \mu \mathrm{L}), 830 \mu \mathrm{L}$ of distilled water and $50 \mu \mathrm{L}$ of sample were pipetted into tube T while $150 \mu \mathrm{L}$ of buffer and $830 \mu \mathrm{L}$ of distilled water were pipetted into tube $\mathrm{B}$. The contents of the tubes were incubated for 

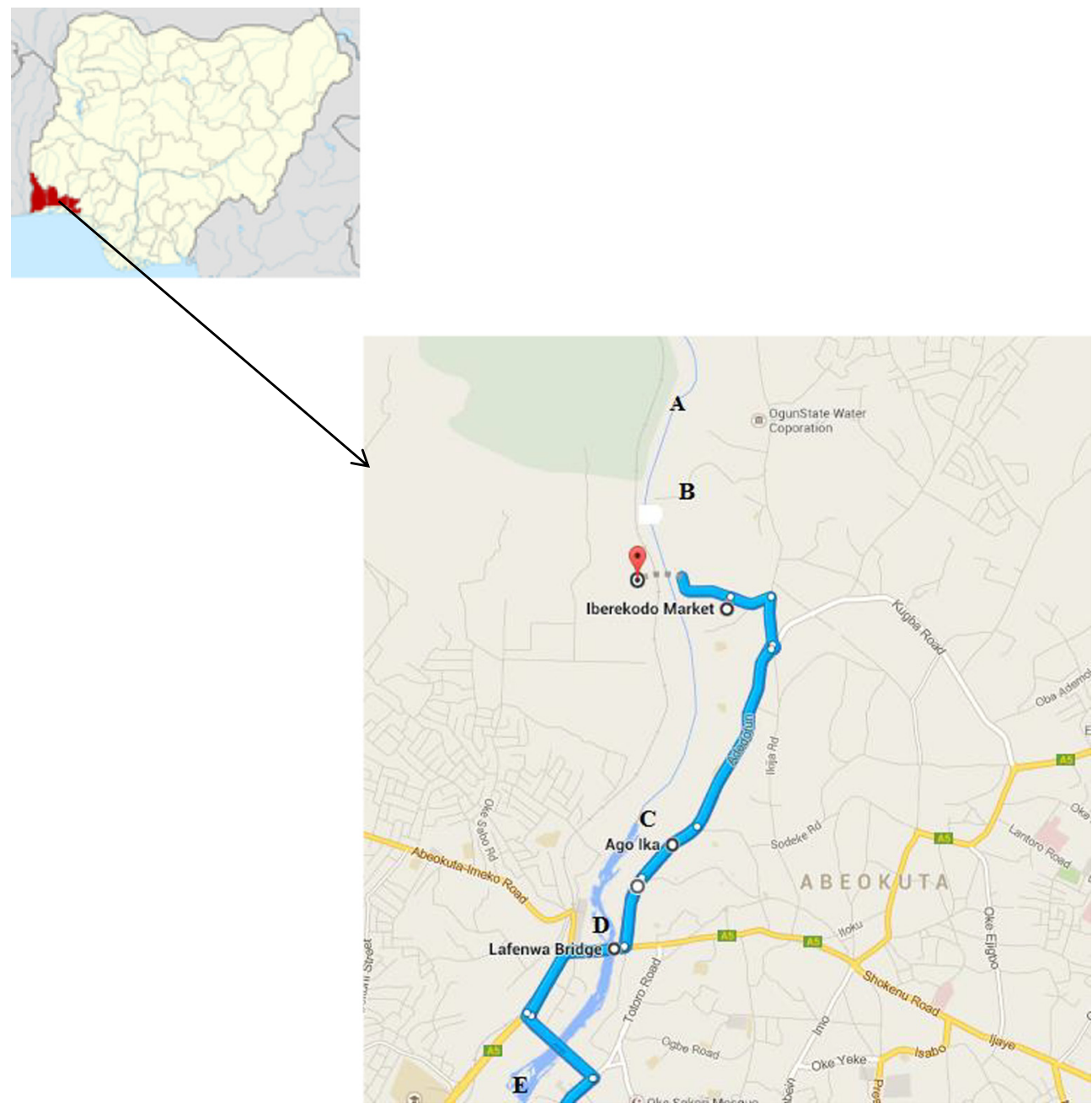

Fig. 1. A map showing the selected sampling points along Ogun River; A-Arakanga; B-Iberekodo; C-Ago-Ika; D-Sokori; E-Enugada.

10 min at $25^{\circ} \mathrm{C}$ and $20 \mu \mathrm{L}$ of pyrogallol was added to both tubes. The contents were mixed by inversion and absorbance at $420 \mathrm{~nm}$ was recorded for $3 \mathrm{~min}$. The difference between the initial and final absorbance and average absorbance difference was calculated $(\triangle \mathrm{A} 4200 /$ min). Superoxide dismutase activity was calculated as

$\%$ Inhibition $=\frac{(\Delta \mathrm{A} 420 \mathrm{~nm} / \text { minblank }-\Delta \mathrm{A} 420 \mathrm{~nm} / \text { mintest })(100)}{\Delta \mathrm{A} 420 \mathrm{~nm} / \text { minblank }}$

Units of SOD $=\frac{\% \text { inhibition }}{(100-\% \text { inhibition })}$

Units $/ \mathrm{mL}=$ Units $\times$ dilution factor

\subsection{Determination of peroxidase}

Peroxidase activity was determined according to the method of Fergusson and Chance (1955). Two test tubes marked blank (B) and test $(\mathrm{T})$ were arranged in a test tube rack. Potassium phosphate buffer $(120 \mu \mathrm{L}), 700 \mu \mathrm{L}$ of distilled water, $50 \mu \mathrm{L}$ of hydrogen peroxide and $100 \mu \mathrm{L}$ of pyrogallol were pipetted into tube T while $150 \mu \mathrm{L}$ of buffer and $700 \mu \mathrm{L}$ of distilled, $50 \mu \mathrm{L}$ of hydrogen peroxide and $100 \mu \mathrm{L}$ of pyrogallol water were pipetted into tube $B$. The tubes were incubated for $10 \mathrm{~min}$ at $25^{\circ} \mathrm{C}$ and $20 \mu \mathrm{L}$ of pyrogallol was added to both tubes. Incubation was carried out for $3 \mathrm{~min}$ at room temperature then $30 \mu \mathrm{L}$ of sample was added to tube $\mathrm{T}$. They were mixed by inversion and absorbance at
$420 \mathrm{~nm}$ was recorded for $5 \mathrm{~min}$. The difference between the initial and final absorbance and average absorbance difference was calculated $(\Delta \mathrm{A}$ $420 \mathrm{~nm} / 20 \mathrm{~s}$ ) for both test and blank. Peroxidase activity was calculated as Units $/ \mathrm{mL}$ enzyme $=\frac{(\Delta \mathrm{A} 420 \mathrm{~nm} / 20 \mathrm{~s} \text { test }-\Delta \mathrm{A} 420 \mathrm{~nm} / 20 \mathrm{~s} \text { blank })(\mathrm{df})}{12 \times 0.03 .}$.

where

$\mathrm{df}=$ Dilution factor

$12=$ Millimolar extinction coefficient of purpurogallin

$0.03 \mathrm{~mL}=$ Volume of enzyme used

Units $/ \mathrm{mg}$ protein $=\frac{\text { Units } / \mathrm{mL}}{\mathrm{mg} \text { protein } / \mathrm{mL}}$

\subsection{Determination of glutathione}

Glutathione concentration was determined according to the method of Ellman (1959). Sample $(500 \mu \mathrm{L})$ was added to $0.5 \mathrm{~mL}$ of $10 \% \mathrm{TCA}$ and the mixture was centrifuged for $15 \mathrm{~min}$ at $3000 \mathrm{rpm}$ following which $0.4 \mathrm{~mL}$ of the supernatant was withdrawn and added to $0.8 \mathrm{~mL}$ of $0.4 \mathrm{M}$ Tris buffer $\mathrm{pH} 8.9$ and $20 \mu \mathrm{L}$ of freshly prepared DTNB. Absorbance was read within 5 min of addition of DTNB at $412 \mathrm{~nm}$ against a blank containing of water instead of erythrocytes. The concentration of glutathione was calculated as $\mathrm{mM} \mathrm{GSH}=($ Absorbance $/ 14.15) \times 2.44 \times$ dilution factor.

Where (14.15 $\left.\mathrm{mM}^{-1} \mathrm{~cm}^{-1}\right)$ is the molar extinction coefficient of NTB and 2.44 is the dilution factor of sample in $1.22 \mathrm{~mL}$ assay mixture. 


\subsection{Extraction of DNA}

Extraction of DNA from the organisms was carried out using the Qiagen DNA extraction kit which uses the spin column method. $25 \mathrm{mg}$ of tissue was cut into small pieces, placed in a microcentrifuge tube and $180 \mu \mathrm{L}$ of Buffer ATL and $20 \mu \mathrm{L}$ of proteinase K were added. The content was mixed thoroughly on a vortex mixer and incubated at $56{ }^{\circ} \mathrm{C}$ overnight until the tissues were completely lysed. After complete lysis of the tissue, $200 \mu \mathrm{L}$ of buffer AL was added, mixed thoroughly followed by the addition of $200 \mu \mathrm{L}$ of ethanol (96-100\%). The whole mixture (including any precipitate) was pipetted into the DNeasy mini spin column placed in a $2 \mathrm{~mL}$ collection tube and centrifuged at $6000 \times \mathrm{g}$ for $1 \mathrm{~min}$. The flow through was discarded while the spin column was placed in a new $2 \mathrm{~mL}$ collection tube. After this, $500 \mu \mathrm{L}$ of buffer AW1 was added and centrifuged at 6000 $\times g$ for 1 min. The flow through was discarded while the spin column was placed in a new $2 \mathrm{~mL}$ collection tube and $500 \mu \mathrm{L}$ of buffer AW2 was added, centrifuged at $20000 \times g$ for 3 min to dry the DNeasy membrane and flow through was discarded. The DNeasy mini spin column was then placed in a clean $2 \mathrm{~mL}$ microcentrifuge tube and $200 \mu \mathrm{L}$ of buffer AE was pipetted directly onto the DNeasy membrane and incubation was carried out at room temperature for $1 \mathrm{~min}$ and then centrifuged at $6000 \times g$ for $1 \mathrm{~min}$ to elute the DNA. The eluted DNA was quantified using Fisher Scientific nanodrop spectrophotometer and kept at $-20{ }^{\circ} \mathrm{C}$ until used (Ausubel et al., 2002).

\subsection{Randomly amplified polymorphic DNA fingerprinting polymerase chain reaction ( $R A P D P C R)$}

RAPD PCR was carried out as described by Seufi et al. (2009) using the Qiagen PCR master mix kit. The program used for the PCR has been previously validated/optimized in our laboratory. This optimization involved checking several RAPD primers and circling conditions for effectiveness in these organisms. All the bands that showed on agarose gel were included in the dendrogram analysis.

The primers used for the polymerase chain reaction were:

- EZ: 5'-GCATCACAGACCTGTTATTGCCTC-3'

- OPA2: 5'-TGCCGAGCTG-3'

- OPA3: 5'-AGTCAGCCAC-3'

$12.5 \mu \mathrm{L}$ of $2 \times$ PCR master mix (PCR reaction buffer, dNTP's, and amplitaq) and $0.5 \mu \mathrm{L}$ of primer were pipetted into a DNAase and RNAase free PCR tube. $50 \mu \mathrm{g}$ of the DNA extracted was added and the mixture was made up to $25 \mu \mathrm{L}$ with sterilized, filtered distilled water. The samples were placed in the thermal cycler and PCR was carried out using the programs shown in Table 1. All the PCR reactions were run with negative control. We also used many RAPD primers in study; however, only primers that showed polymorphic bands were reported.

\subsection{Dendrogram construction}

The RAPD fingerprints were used for cluster differentiation and dendrogram construction using a simple agglomerative hierarchical clustering, the Unweighted Pair Group Method with Arithmetic Mean (UPGMA).

\subsection{Data analysis}

Statistical analysis was done using one-way analysis of variance (ANOVA); also, a post hoc test was done to compare the obtained means for each sample. A significance level of 0.05 was used. Also, the bio-concentration factor was determined as a ratio of heavy metals in the tissue of the freshwater prawns and water samples as follows:

\section{Results}

The varying concentrations of selected heavy metals in the sampled earthworms and freshwater prawns are shown in Table 2. Cd concentration in A. millsoni was below detection limit at three sites, while it ranged from $(3.67 \pm 1.53-6.7 \pm 4.04) \mathrm{mg} / \mathrm{kg}$ in L. violaceus. The concentration of $\mathrm{Pb}$ in A. millsoni and $L$. violaceus samples ranged from $(0.75 \pm$ $0.6-39.67 \pm 2.25) \mathrm{mg} / \mathrm{kg}$. Cu and $\mathrm{Zn}$ were detected in the earthworm samples collected from all the sites. $\mathrm{Cu}$ concentration ranged from $(2.50 \pm 1.20-27.0 \pm 13.0) \mathrm{mg} / \mathrm{kg}$ and $(34.0 \pm 27-57.7 \pm 1.25) \mathrm{mg} / \mathrm{kg}$ for A. millsoni and L. violaceus respectively, while the concentration of $\mathrm{Zn}$ was $(287.83 \pm 49.12-685.83 \pm 114) \mathrm{mg} / \mathrm{kg}$ and $(1285 \pm$ 247.4-1913.3 \pm 1098.7$) \mathrm{mg} / \mathrm{kg}$ for A. millsoni and L. violaceus respectively. $\mathrm{Cd}, \mathrm{Pb}$ and $\mathrm{Cr}$ were observed to be below detection limits in soft tissues and shell in prawns collected at Iberekodo and Enugada. Similar$\mathrm{ly}, \mathrm{Cd}, \mathrm{Pb}$ and $\mathrm{Cr}$ were not detected in shells of prawns collected at AgoIka. $\mathrm{Pb}$ concentration in the soft tissue and shell of prawn collected AgoIka and Sokori were $0.67 \mathrm{mg} / \mathrm{L}$ and $2.0 \mathrm{mg} / \mathrm{L}$ respectively. $\mathrm{Cu}$ and $\mathrm{Zn}$ were detected in both tissues and shell of prawn collected at the selected study sites. Cu varied from 48 to $67.67 \mathrm{mg} / \mathrm{kg}$ in the shell and $29.33-60.3 \mathrm{mg} / \mathrm{kg}$, furthermore significant difference $(\mathrm{p}<0.05$ ) was observed in Cu concentration in soft tissues of prawn collected at Arakanga and other sites. Similarly, significant difference $(\mathrm{p}<0.05)$ was observed in $\mathrm{Zn}$ concentration in both tissues of the prawns. Lowest $\mathrm{Zn}$ concentration $(21.3 \mathrm{mg} / \mathrm{kg})$ was recorded for shells of prawns collected at Sokori, and the highest was $85.67 \mathrm{mg} / \mathrm{kg}$ recorded for samples collected at Arakanga. Similarly, significant difference $(p<0.05)$ was observed in the soft tissue of the prawn and it ranged from $59.33-1324.7 \mathrm{mg} / \mathrm{kg}$.

\subsection{Antioxidant concentration in the soft tissues of sampled organism}

A. millsoni samples collected at Enugada recorded the highest SOD ( $79.73 \pm 6.37 \mathrm{U} / \mathrm{g}$ tissues), Peroxidase $(0.15 \pm 0.08 \mathrm{U} / \mathrm{g}$ tissues $)$ and GSH (3.68 $\pm 2.15 \mu \mathrm{M} / \mathrm{g}$ tissues), while samples obtained from Arakanga elicited the highest activity of GST $(0.56 \pm 0.03 \mathrm{U} / \mathrm{g}$ tissues). On the other hand, L. violaceus samples collected at Sokori elicited highest activities for GST and GSH $(0.076 \pm 0.024 \mathrm{U} / \mathrm{g}$ tissues and $1.79 \pm 0.75 \mu \mathrm{M} / \mathrm{g}$ tissues respectively). Significant differences were observed at $\mathrm{p}<0.05$. The varying activities of these antioxidants in the sampled limicolous earthworms are presented in Table 3.

The mean concentrations of the soft tissues of $M$. vollenhovenii are showed in the Table 3. SOD (U/g tissues) activities were the highest

Table 1

Pattern of PCR operation for amplifying primers.

\begin{tabular}{|c|c|c|c|c|c|c|c|c|c|c|}
\hline & \multicolumn{10}{|l|}{ Stages } \\
\hline & 1 & 2 & 3 & 4 & 5 & 6 & 7 & 8 & 9 & 10 \\
\hline EZ & $94^{\circ} \mathrm{C}, 1: 00 \mathrm{~min}$ & $54.6^{\circ} \mathrm{C}, 2: 00 \mathrm{~min}$ & $72{ }^{\circ} \mathrm{C}, 2: 00 \mathrm{~min}$ & Goto $1,5 \times$ & $94{ }^{\circ} \mathrm{C}, 0: 15 \mathrm{~min}$ & $59.6^{\circ} \mathrm{C}, 0: 30 \mathrm{~min}$ & $72{ }^{\circ} \mathrm{C}, 1: 00 \mathrm{~min}$ & Goto $5,45 \times$ & $72{ }^{\circ} \mathrm{C}, 15: 00 \mathrm{~min}$ & $4{ }^{\circ} \mathrm{C}, \infty$ \\
\hline OPA2 & $94^{\circ} \mathrm{C}, 1: 00 \mathrm{~min}$ & $29^{\circ} \mathrm{C}, 2: 00 \mathrm{~min}$ & $72^{\circ} \mathrm{C}, 2: 00 \mathrm{~min}$ & Goto $1,5 \times$ & $94{ }^{\circ} \mathrm{C}, 1: 00 \mathrm{~min}$ & $34^{\circ} \mathrm{C}, 0: 30 \mathrm{~min}$ & $72{ }^{\circ} \mathrm{C}, 1: 00 \mathrm{~min}$ & Goto $5,45 \times$ & $72{ }^{\circ} \mathrm{C}, 15: 00 \mathrm{~min}$ & $4{ }^{\circ} \mathrm{C}, \infty$ \\
\hline OPA3 & $94^{\circ} \mathrm{C}, 1 \mathrm{~min}$ & $27^{\circ} \mathrm{C}, 2 \mathrm{~min}$ & $72{ }^{\circ} \mathrm{C}, 2 \mathrm{~min}$ & Goto $1,5 \times$ & $94{ }^{\circ} \mathrm{C}, 1: 00 \mathrm{~min}$ & $32{ }^{\circ} \mathrm{C}, 0: 30 \mathrm{~min}$ & $72^{\circ} \mathrm{C}, 1: 00 \mathrm{~min}$ & Goto $5,45 \times$ & $72{ }^{\circ} \mathrm{C}, 15: 00 \mathrm{~min}$ & $4{ }^{\circ} \mathrm{C}, \infty$ \\
\hline
\end{tabular}


Table 2

Heavy metal concentrations ( $\mathrm{mg} / \mathrm{kg}$ ) in Alma millsoni, Libyodrilus violaceus and M. vollenhovenii (soft tissues and shell) collected from different points of Ogun River.

\begin{tabular}{|c|c|c|c|c|c|}
\hline \multirow[t]{2}{*}{ Heavy metals/test organisms } & \multicolumn{5}{|c|}{ Sampling Points of Ogun River } \\
\hline & Iberekodo & Ago-ika & Enugada & Sokori & Arakanga \\
\hline \multicolumn{6}{|l|}{$\mathrm{Cd}(\mathrm{mg} / \mathrm{kg})$} \\
\hline A. millsoni & BDL & BDL & $4.3 \pm 2.3^{\mathrm{a}}$ & BDL & $5.3 \pm 1.5^{\mathrm{a}}$ \\
\hline L. violaceus & $4.7 \pm 4.6^{\mathrm{a}}$ & $6.3 \pm 2.08^{\mathrm{a}}$ & $5.67 \pm 3.79^{\mathrm{a}}$ & $3.67 \pm 1.53^{\mathrm{a}}$ & $6.7 \pm 4.04^{\mathrm{a}}$ \\
\hline M. vollenhovenii (soft tissue) & $\mathrm{BDL}$ & $\mathrm{BDL}$ & $\mathrm{BDL}$ & $\mathrm{BDL}$ & $\mathrm{BDL}$ \\
\hline M. vollenhovenii (shell) & $\mathrm{BDL}$ & $\mathrm{BDL}$ & BDL & $\mathrm{BDL}$ & $3.33 \pm 2.89$ \\
\hline \multicolumn{6}{|l|}{$\mathrm{Pb}(\mathrm{mg} / \mathrm{kg})$} \\
\hline A. millsoni & $3.3 \pm 3.1^{\mathrm{a}}$ & $\mathrm{BDL}$ & $38.5 \pm 33.0^{\mathrm{a}}$ & $\mathrm{BDL}$ & $56.8 \pm 42.8^{\mathrm{b}}$ \\
\hline L. violaceus & $39.3 \pm 34.1^{\mathrm{a}}$ & $70.7 \pm 9.1^{b}$ & $85.7 \pm 49.5^{\mathrm{b}}$ & $60.0 \pm 33.0^{\mathrm{b}}$ & $25.2 \pm 16.8^{\mathrm{a}}$ \\
\hline M. vollenhovenii (soft tissue) & BDL & $0.7 \pm 1.2^{\mathrm{a}}$ & BDL & BDL & $1.3 \pm 1.5^{\mathrm{a}}$ \\
\hline M. vollenhovenii (shell) & BDL & $\mathrm{BDL}$ & $\mathrm{BDL}$ & $2.0 \pm 3.46^{\mathrm{a}}$ & $0.33 \pm 0.6^{\mathrm{a}}$ \\
\hline \multicolumn{6}{|l|}{$\mathrm{Cr}(\mathrm{mg} / \mathrm{kg})$} \\
\hline A. millsoni & BDL & $26.3 \pm 17.6^{\mathrm{b}}$ & $3.7 \pm 6.4^{\mathrm{a}}$ & BDL & $20.0 \pm 18.3^{\mathrm{b}}$ \\
\hline L. violaceus & BDL & $14.7 \pm 4.9^{\mathrm{a}}$ & $14.7 \pm 4.7^{\mathrm{a}}$ & $15.0 \pm 5.3^{\mathrm{a}}$ & $13.3 \pm 12.2^{\mathrm{a}}$ \\
\hline M. vollenhovenii (soft tissue) & BDL & BDL & BDL & $8.0 \pm 13.9^{\mathrm{a}}$ & $56.0 \pm 49.7^{\mathrm{b}}$ \\
\hline M. vollenhovenii (shell) & BDL & $\mathrm{BDL}$ & BDL & $\mathrm{BDL}$ & BDL \\
\hline \multicolumn{6}{|l|}{$\mathrm{Cu}(\mathrm{mg} / \mathrm{kg})$} \\
\hline A. millsoni & $13.7 \pm 1.5^{\mathrm{a}}$ & $10.0 \pm 7.8^{\mathrm{a}}$ & $44.7 \pm 14.5^{\mathrm{b}}$ & $12.0 \pm 2.0^{\mathrm{a}}$ & $53.3 \pm 26.3^{b}$ \\
\hline L. violaceus & $42.3 \pm 6.5^{\mathrm{a}}$ & $57.7 \pm 1.2^{\mathrm{a}}$ & $42.0 \pm 15.5^{\mathrm{a}}$ & $46.2 \pm 15.8^{a}$ & $34.0 \pm 27.6^{\mathrm{a}}$ \\
\hline M. vollenhovenii (soft tissue) & $29.3 \pm 1.2^{\mathrm{a}}$ & $30.0 \pm 8.7^{\mathrm{a}}$ & $36.7 \pm 4.6^{\mathrm{ab}}$ & $34.0 \pm 2.3^{\mathrm{ab}}$ & $60.3 \pm 32.7^{\mathrm{b}}$ \\
\hline M. vollenhovenii (shell) & $62.3 \pm 27.7^{b}$ & $60.3 \pm 11.0^{\mathrm{b}}$ & $65.7 \pm 7.8^{\mathrm{b}}$ & $48 \pm 8.7^{\mathrm{a}}$ & $67.7 \pm 50.4^{\mathrm{b}}$ \\
\hline \multicolumn{6}{|l|}{$\mathrm{Zn}(\mathrm{mg} / \mathrm{kg})$} \\
\hline A. millsoni & $1356.0 \pm 249.5^{\mathrm{a}}$ & $1151.3 \pm 196.5^{\mathrm{a}}$ & $1282.3 \pm 877.0^{\mathrm{a}}$ & $1420.0 \pm 58.6^{\mathrm{a}}$ & $1770.7 \pm 596.3^{\mathrm{b}}$ \\
\hline L. violaceus & $1809.3 \pm 941.1^{\mathrm{b}}$ & $1714.7 \pm 738.9^{\mathrm{b}}$ & $1285 \pm 247.4^{\mathrm{a}}$ & $1295.3 \pm 92.1^{\mathrm{a}}$ & $1913.3 \pm 1098.7^{\mathrm{b}}$ \\
\hline M. vollenhovenii (soft tissue) & $78.0 \pm 24.3^{\mathrm{a}}$ & $76.0 \pm 9.2^{\mathrm{a}}$ & $59.3 \pm 28.4^{\mathrm{a}}$ & $84.7 \pm 9.9^{\mathrm{a}}$ & $134.7 \pm 13.6^{\mathrm{b}}$ \\
\hline M. vollenhovenii (shell) & $52.7 \pm 20.5^{\mathrm{ab}}$ & $49.7 \pm 20.6^{\mathrm{ab}}$ & $57.0 \pm 12.8^{\mathrm{ab}}$ & $21.3 \pm 4.6^{\mathrm{a}}$ & $85.7 \pm 33.1^{\mathrm{b}}$ \\
\hline
\end{tabular}

Means with the same superscript in a row are not significantly different $(\mathrm{p}>0.05)$.

$\mathrm{BDL}=$ below detection limit.

among the selected antioxidant biomarkers. Furthermore, there was no significant difference $(\mathrm{p}<0.05)$ in SOD activities in the soft tissues of $M$. vollenhovenii collected from the selected sites. Similarly, Peroxidase and GSH activities also showed no significant difference ( $p>0.05$ ) but had the highest mean 0.022 recorded for Enugada and Sokori. On the other hand, significant difference $(\mathrm{p}<0.05)$ was observed in the GST production, as means varied from $0.035-0.078$ (U/g tissues).

Table 4 showed the Pearson's product-moment correlation to assess the relationships between the antioxidant enzymes and heavy metals; SOD had a moderate negative correlation with Lead $(\mathrm{r}=-0.343, \mathrm{p}<$ $0.05)$; and strong negative correlation with Zinc $(\mathrm{r}=-0.463, \mathrm{p}<$
0.05).The relationship between SOD and the other metals was negative but not significant. Peroxidase correlates strongly positive with Cadmi$\mathrm{um}(\mathrm{r}=0.459, \mathrm{p}<0.01)$, Lead $(\mathrm{r}=0.396, \mathrm{p}<0.01)$ and $\operatorname{Zinc}(\mathrm{r}=0.538$, $\mathrm{p}<0.01)$; Cadmium had strong positive correlation with Lead $(\mathrm{r}=0.881$, $\mathrm{p}<0.01)$, Chromium $(\mathrm{r}=0.394, \mathrm{p}<0.01)$, Copper $(\mathrm{r}=0.816, \mathrm{p}<0.01)$ and Zinc $(r=0.760, p<0.01)$ while Lead had strong positive correlation with Chromium $(r=0.627, \mathrm{p}<0.01)$, Copper $(\mathrm{r}=0.820, \mathrm{p}<0.01)$ and Zinc $(\mathrm{r}=0.789, \mathrm{p}<0.01)$; Chromium also correlates strongly positive with Copper $(\mathrm{r}=0.433, \mathrm{p}<0.01)$ and Zinc $(\mathrm{r}=0.544, \mathrm{p}<0.01)$ while Copper had a strong positive correlation with Zinc $(r=0.646, p<0.01)$. A strong positive correlation was found between GST and GSH $(r=$ $0.470, \mathrm{p}<0.01$ ).

Table 3

Antioxidant enzymes activities in Alma millsoni, Libyodrilus violaceus and M. vollenhovenii (soft tissues and shell) collected from different points of Ogun River.

\begin{tabular}{|c|c|c|c|c|c|}
\hline \multirow[t]{2}{*}{ Antioxidants/test organisms } & \multicolumn{5}{|l|}{ Sampling Points } \\
\hline & Iberekodo & Ago-Ika & Enugada & Sokori & Arakanga \\
\hline \multicolumn{6}{|l|}{ SOD (U/g tissue) } \\
\hline A. millsoni & $62.44 \pm 7.16^{\mathrm{a}}$ & $74.91 \pm 14.10^{\mathrm{a}}$ & $79.73 \pm 6.37^{\mathrm{a}}$ & $79.82 \pm 11.18^{\mathrm{a}}$ & $65.64 \pm 8.86^{\mathrm{a}}$ \\
\hline L. violaceus & $62.11 \pm 13.89^{\mathrm{a}}$ & $64.01 \pm 6.24^{\mathrm{a}}$ & $71.07 \pm 7.54^{\mathrm{a}}$ & $60.26 \pm 11.18^{\mathrm{a}}$ & $65.64 \pm 8.86^{\mathrm{a}}$ \\
\hline M. vollenhovenii & $74.07 \pm 16.69^{a}$ & $85.42 \pm 2.87^{\mathrm{a}}$ & $83.95 \pm 8.04^{\mathrm{a}}$ & $87.79 \pm 8.50^{\mathrm{a}}$ & $79.29 \pm 4.14^{\mathrm{a}}$ \\
\hline \multicolumn{6}{|l|}{ Peroxidase (U/g tissue) } \\
\hline A. millsoni & $0.07 \pm 0.03^{\mathrm{a}}$ & $0.11 \pm 0.06^{\mathrm{a}}$ & $0.15 \pm 0.08^{\mathrm{a}}$ & $0.12 \pm 0.05^{\mathrm{a}}$ & $0.11 \pm 0.10^{\mathrm{a}}$ \\
\hline L. violaceus & $0.05 \pm 0.02^{\mathrm{a}}$ & $0.11 \pm 0.06^{\mathrm{a}}$ & $0.10 \pm 0.11^{\mathrm{a}}$ & $0.19 \pm 0.18^{\mathrm{a}}$ & $0.17 \pm 0.14^{\mathrm{a}}$ \\
\hline M. vollenhovenii & $0.01 \pm 0.003^{\mathrm{a}}$ & $0.019 \pm 0.006^{\mathrm{a}}$ & $0.022 \pm 0.018^{\mathrm{a}}$ & $0.022 \pm 0.11^{\mathrm{a}}$ & $0.015 \pm 0.11^{\mathrm{a}}$ \\
\hline \multicolumn{6}{|l|}{ GST (U/g tissue) } \\
\hline A. millsoni & $0.05 \pm 0.04^{\mathrm{a}}$ & $0.06 \pm 0.02^{\mathrm{a}}$ & $0.15 \pm 0.12^{\mathrm{a}}$ & $0.07 \pm 0.04^{\mathrm{a}}$ & $0.56 \pm 0.03^{\mathrm{b}}$ \\
\hline L. violaceus & $0.01 \pm 0.004^{\mathrm{a}}$ & $0.022 \pm 0.018^{\mathrm{a}}$ & $0.024 \pm 0.032^{\mathrm{a}}$ & $0.019 \pm 0.009^{a}$ & $0.076 \pm 0.024^{\mathrm{b}}$ \\
\hline M. vollenhovenii & $0.035 \pm 0.016^{\mathrm{a}}$ & $0.042 \pm 0.011^{\mathrm{ab}}$ & $0.069 \pm 0.007^{\mathrm{ab}}$ & $0.048 \pm 0.013^{\mathrm{ab}}$ & $0.078 \pm 0.04^{\mathrm{b}}$ \\
\hline \multicolumn{6}{|l|}{ GSH (U/g tissue) } \\
\hline A. millsoni & $1.57 \pm 0.26^{\mathrm{a}}$ & $2.19 \pm 0.63^{\mathrm{a}}$ & $3.68 \pm 2.15^{\mathrm{a}}$ & $3.26 \pm 2.12^{\mathrm{a}}$ & $1.96 \pm 2.53^{\mathrm{a}}$ \\
\hline L. violaceus & $0.51 \pm 0.17^{\mathrm{a}}$ & $0.91 \pm 0.50^{\mathrm{b}}$ & $1.10 \pm 0.51^{\mathrm{b}}$ & $1.79 \pm 0.75^{\mathrm{c}}$ & $0.63 \pm 2.53^{\mathrm{a}}$ \\
\hline M. vollenhovenii & $0.77 \pm 0.35^{\mathrm{a}}$ & $1.00 \pm 0.58^{\mathrm{a}}$ & $1.72 \pm 1.64^{\mathrm{a}}$ & $1.22 \pm 0.51^{\mathrm{a}}$ & $1.04 \pm 0.24^{\mathrm{a}}$ \\
\hline
\end{tabular}

Means with the same superscript in a row are not significantly different $(\mathrm{p}>0.05)$ 
Table 4

Correlation co-efficient between concentration of heavy metals and activities of antioxidant enzymes in the tissues of selected test organism.

\begin{tabular}{|c|c|c|c|c|c|c|c|c|c|}
\hline & $\begin{array}{l}\text { SOD } \\
\text { (U/g tissue) }\end{array}$ & $\begin{array}{l}\text { Peroxidase } \\
\text { (U/g tissue) }\end{array}$ & $\begin{array}{l}\text { GST } \\
\text { (U/g tissue) }\end{array}$ & $\begin{array}{l}\text { GSH } \\
(\mu \mathrm{M} / \mathrm{g} \text { tissue })\end{array}$ & $\begin{array}{l}\text { Cadmium } \\
(\mathrm{mg} / \mathrm{kg})\end{array}$ & $\begin{array}{l}\text { Lead } \\
(\mathrm{mg} / \mathrm{kg})\end{array}$ & $\begin{array}{l}\text { Chromium } \\
(\mathrm{mg} / \mathrm{kg})\end{array}$ & $\begin{array}{l}\text { Copper } \\
(\mathrm{mg} / \mathrm{kg})\end{array}$ & $\begin{array}{l}\text { Zinc } \\
(\mathrm{mg} / \mathrm{kg})\end{array}$ \\
\hline $\begin{array}{l}\text { SOD } \\
\text { (U/g tissue) }\end{array}$ & 1 & & & & & & & & \\
\hline $\begin{array}{l}\text { Peroxidase } \\
\text { (U/g tissue) }\end{array}$ & -0.166 & 1 & & & & & & & \\
\hline $\begin{array}{l}\text { GST } \\
\text { (U/g tissue) }\end{array}$ & 0.265 & 0.203 & 1 & & & & & & \\
\hline $\begin{array}{l}\text { GSH } \\
(\mu \mathrm{M} / \mathrm{g} \text { tissue })\end{array}$ & 0.214 & 0.172 & $0.470^{\mathrm{b}}$ & 1 & & & & & \\
\hline $\begin{array}{l}\text { Cadmium } \\
(\mathrm{mg} / \mathrm{kg})\end{array}$ & -0.275 & $0.459^{b}$ & -0.023 & -0.082 & 1 & & & & \\
\hline $\begin{array}{l}\text { Lead } \\
(\mathrm{mg} / \mathrm{kg})\end{array}$ & $-0.343^{a}$ & $0.396^{\mathrm{b}}$ & -0.062 & -0.080 & $0.881^{\mathrm{b}}$ & 1 & & & \\
\hline $\begin{array}{l}\text { Chromium } \\
(\mathrm{mg} / \mathrm{kg})\end{array}$ & -0.267 & 0.262 & -0.219 & 0.125 & $0.394^{\mathrm{b}}$ & $0.627^{\mathrm{b}}$ & 1 & & \\
\hline $\begin{array}{l}\text { Copper } \\
(\mathrm{mg} / \mathrm{kg})\end{array}$ & -0.149 & 0.232 & -0.104 & -0.019 & $0.816^{\mathrm{b}}$ & $0.820^{\mathrm{b}}$ & $0.433^{\mathrm{b}}$ & 1 & \\
\hline $\begin{array}{l}\text { Zinc } \\
(\mathrm{mg} / \mathrm{kg})\end{array}$ & $-0.463^{b}$ & $0.538^{\mathrm{b}}$ & -0.043 & 0.106 & $0.760^{\mathrm{b}}$ & $0.789^{b}$ & $0.544^{\mathrm{b}}$ & $0.646^{\mathrm{b}}$ & 1 \\
\hline
\end{tabular}

a Correlation is significant at the 0.05 level (2-tailed).

b Correlation is significant at the 0.01 level (2-tailed).

\subsection{DNA profile}

The agarose gel photographs for the randomly amplified polymorphic genomic DNA (RAPD) performed on the limicolous earthworms and freshwater prawns collected at five sampling sites of Ogun River is shown in Plates 1 and 2. Results showed that molecular weight used ranged from (1000-10,000) bp. Agarose gel photographs for freshwater prawns abdominal tissues showed similar

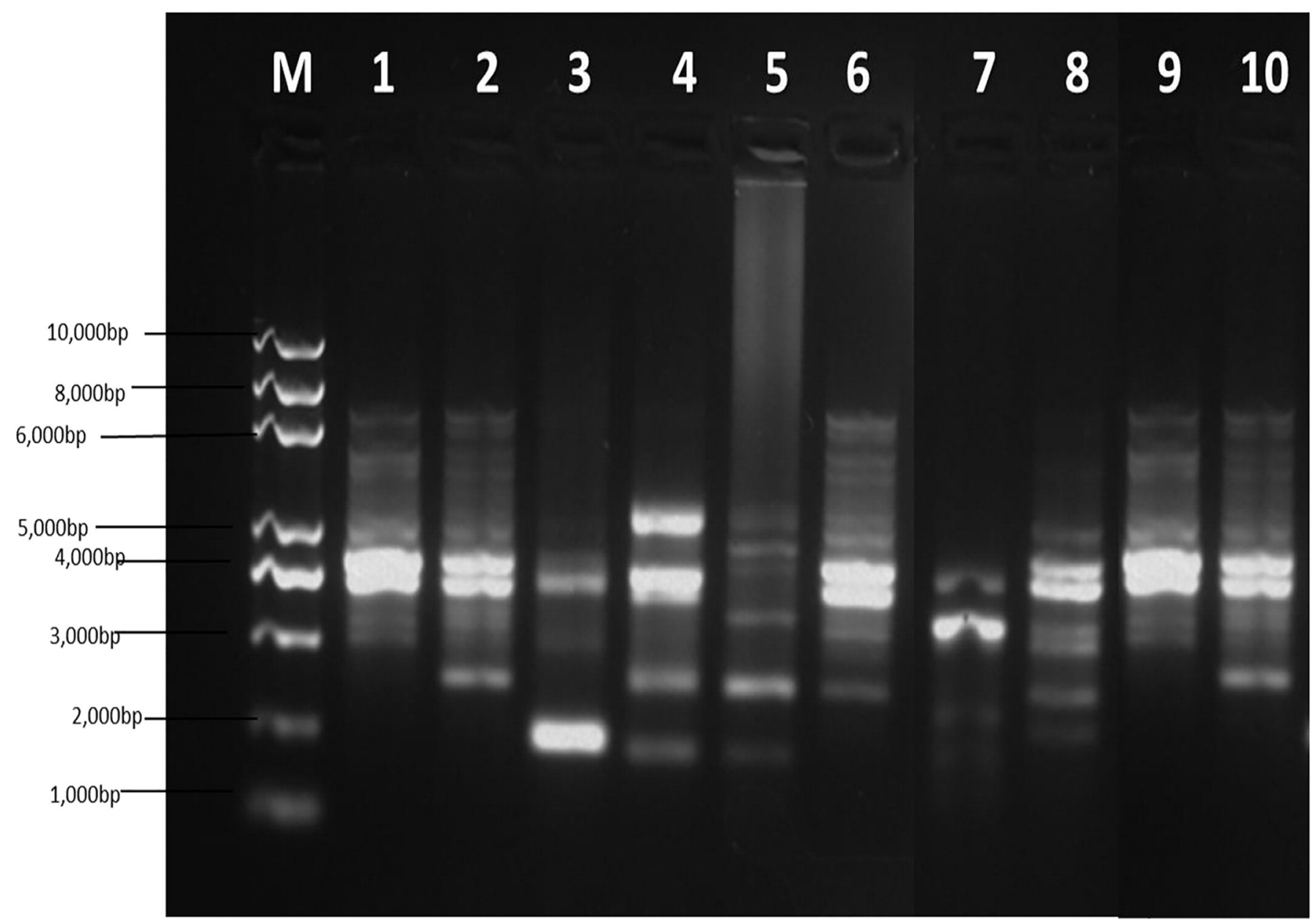

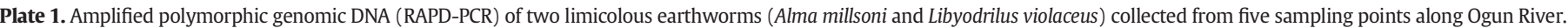

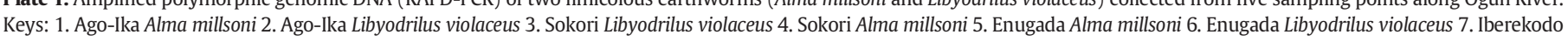
Libyodrilus violaceus 8. Iberekodo Alma millsoni 9. Arakanga Alma millsoni 10. Arakanga Libyodrilus violaceus. 
DNA band patterns and hence having similar molecular weight marker. In the limicolous earthworms, molecular weight marker at 4000 bp was consistent in most of the genome in the test earthworms except in the genome of lane 3, 5 and 7.

\subsection{Dendrogram clustering}

The dendrogram obtained from cluster analysis by UPGMA is shown in Fig. 2. Two clusters A and B were obtained at about genetic similarity coefficient of 0.15-0.2. Cluster A diverged earlier at coefficient 0.2 and consist of Alma millsoni and Libyodrilus violaceus from Sokori, Enugada and Iberekodo sampling points. Cluster B diverged later than A forming two distinct sub-clusters comprising Arakanga and Ago-Ika L. violaceus in one and A. millsoni in the other.

\section{Discussion}

Freshwater macro-invertebrates such as freshwater prawns and limicolous earthworms inhabiting heavy metal polluted aquatic environment could serve as sentinel species of freshwater system (Suarez-Serrano et al., 2010). Table 2 reflects varied concentration of heavy metals in the test organisms, the choice for these metals was because, the two essential metals $(\mathrm{Cu}$ and $\mathrm{Zn})$ that are relevant for body metabolism but which become toxic at higher concentrations and two non-essential metals ( $\mathrm{Cr}$ and $\mathrm{Cd}$ ), that are not needed in biological systems. Furthermore, other researcher works such as Dedeke et al. (2016) have shown that these metal have a questionable characteristics (such pro-oxidants with potentials for inducing oxidative DNA damage) when bioaccumulated in living biological systems. Furthermore, the positive relationship between metals depicts a synergic effect in the living tissues, this findings supported that suggestion of Ubwa et al. (2013) who stated that the metal were from the same environment.

Among the selected heavy metals; tissue loads of $\mathrm{Cu}$ and $\mathrm{Zn}$ in $\mathrm{A}$. millsoni, L. violaceus and $M$. vollenhovenii collected from all sampling points were higher than other selected metals. This is similar to the study of Nannoni et al. (2011), Heidarieh et al. (2013) and Abdel-Salam and Hamdi $(2014,2015)$ that reported higher concentrations of similar metals in earthworm species (Nicodrilus caliginosus), swimmer crabs and (shrimps) Penaeus semisulcatus respectively. High concentration of these metals ( $\mathrm{Cu}$ and $\mathrm{Zn}$ ) can be linked to the essential roles they play in enzymatic activities and cell protection growth in a

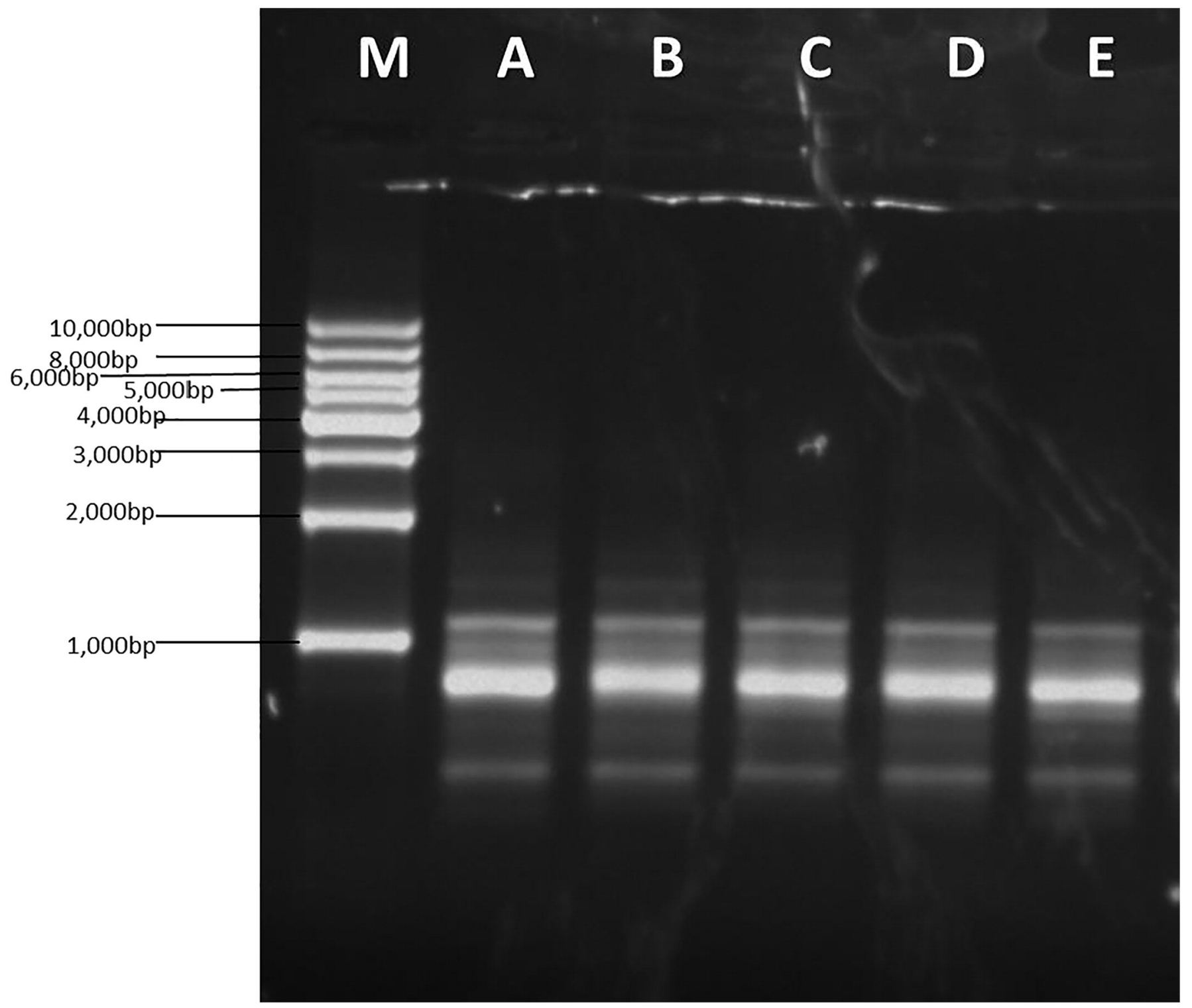

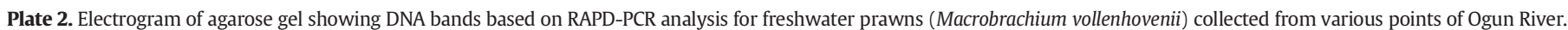




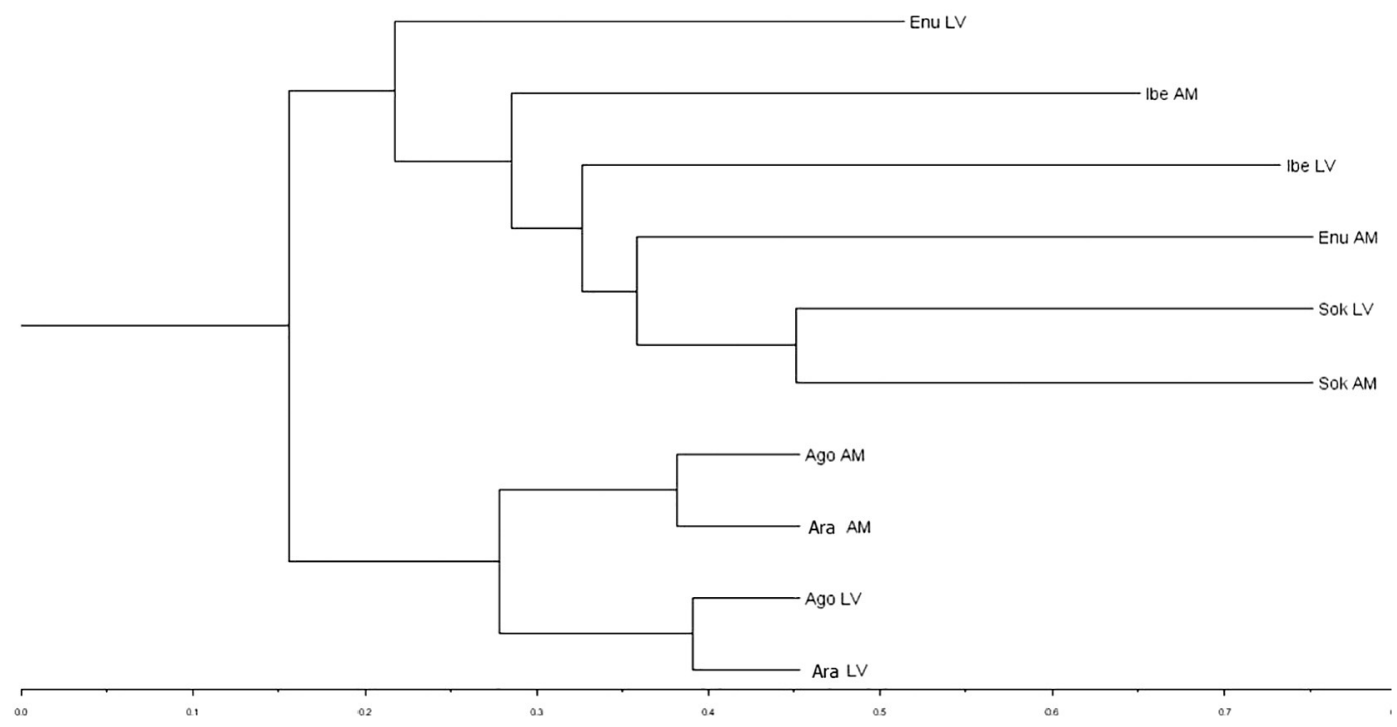

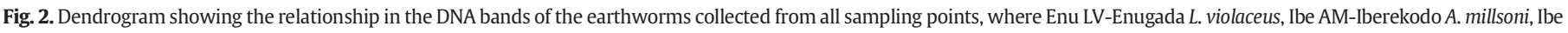

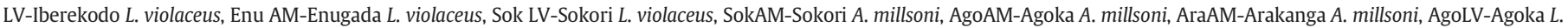
violaceus, AraLV-Arakanga L. violaceus.

living biological system. Also, as reported by Mitra et al. (2010), these metals easily diffuse across the membrane surface as a soluble complex surface.

The test organisms (limicolous earthworms and freshwater prawns) utilize varieties of sequestration mechanisms to tolerate heavy metal bioaccumulation. The freshwater prawn can maintain homeostasis, detoxify heavy metals in their hepatopancreas and bind metals to low molecular weight proteins like metallothioneins, store metals in lysosome, shell or metal granules in the cells in the freshwater prawns (Abdolahpur et al., 2013 and Meshram et al., 2014). Andre et al. (2009) reported that, metals are mostly accumulated at the posterior end of the alimentary canal in the earthworm, this part is made up of pedunculated cells (chloragogenous tissue) whose role is to synthesize haemoglobin, maintain homeostasis and $\mathrm{pH}$ level, store nutrients and waste, uptake and detoxification of toxic cations (Morgan et al., 2002).

The difference in metal bioaccumulation between the different tests organisms may be due to their varying metabolic pathways, habitat use and behavioural responses. Furthermore, lesser accumulation of heavy metals in the $M$. vollenhovenii in this study as opposed to the earthworms could also be attributed to the constant shedding of its chitinous exoskeletal shell which occurs in $M$. vollenhovenii as it grows. This finding is consistent with an earlier report pointing to lower concentration of heavy metals in shrimp due to molting behaviour (Soundarapandian et al., 2010).

Oxidative stress and production of reactive oxygen species have been reported to be positively correlated with heavy metal accumulation in organisms (Orebiyi et al., 2010; Tumminello and Fuller-Espie, 2013). Production of antioxidants is a biochemical means by which organisms responds to metal accumulation; this reduces or repairs the damages caused by the free radicals. The differential metal accumulation observed in the test organisms influenced the activities of antioxidants produced. These findings are similar to the study of Atli and Canli (2010), Cataldo et al. (2011) and Owagboriaye (2014).

SOD activities appeared to be higher than other antioxidants measured in the test organisms. This may be attributed to the fact that SOD can also be produced naturally during metabolic process such as mitochondria electron transport chain, cytochrome p450 monooxygenases, however, a yet higher concentration would be produced or a higher activity of the enzyme will occur in response to pollution challenge such as heavy metal bioaccumulation. For the present study, heavy metal concentration in the environment and living tissues could have elicited the production of more superoxide anion. This result was also observed in freshwater teleost exposed to mercury (Moriom and Mahuya, 2014). This level of activity implies that SOD is a vital protective antioxidant used by freshwater organisms against the toxic effects of free radicals produced as a result of heavy metal bioaccumulation. On the other hand, peroxidase and GST activities were observed to be low and all sampled tissues showed a depletion of GSH activities. Similar report was recorded for Orechromis niloticus exposed to copper toxicity (Saglam et al., 2014). Lopez-Lopez et al. (2011) pointed out that acute heavy metal toxicity has the tendency to impair the formation of these protective antioxidants. It is vital to note that reactive oxygen species (ROS) such as superoxide ion generated as a result of influx of ionic metals, attacks macromolecules such as DNA, hence, may cause its DNA damage (Valko et al., 2005), but antioxidants serve to eliminate or repair the damage caused by ROS. Hence we could say, antioxidant acts as protective agents for macromolecules such as the nucleic acid.

RAPD-PCR band pattern of the limicolous earthworms showed that some band consistently appeared at a particular base pair and, this was comparable to the findings of Galindo et al. (2010) who used the same technique on gills and liver exposed to different doses of Aluminum. Usually the information of a pattern is based on the generated number of bands, allowing a variability due to artifacts that has to be considered and if possible measured.

The number of generated bands for each group (the DNA fingerprint) was used in scoring the level of polymorphism and the scores were used for cluster analysis and generation of the dendrogram.

The interaction between genotoxic agents and DNA can result in modification of its structure, appearance and functions as suggested by Noel and Rath (2006). This was further confirmed by the dendrogram in which dissimilar limicolous species (A. millisoni and L. violaceus) collected from the same environment (Sokori) clustered together. Earthworm Cluster A from the result showed higher level of genetic variability among them probably as a result of mutation due to exposure to higher doses of heavy metals. On the hand, those in Cluster B are more genetically stable and closely similar probably indicating that Arakanga and Ago-Ika points of Ogun River are less polluted with heavy metal. The DNA band pattern of the freshwater prawn, M. vollenhovenii, collected at the various sampling points of Ogun River indicated no adverse mutagenic effect of exposure to this environment. 
This result agrees with the reports of Cambier et al. (2010) which stated that all genomes are not equally sensitive to the impact of genotoxic substances such as heavy metals. Hence, inactive chromatin may be protected and less prone to genetic modifications. This may also be due to differences in sensitivity depending on primer sequence (Zohra et al., 2014). The observed difference between the DNA profile of the limicolous earthworms and freshwater prawns may also be due to duration of exposure and concentration of heavy metals (Mohamed et al., 2012). The earthworms unlike the prawns were burrowers by nature and are found partly buried in the marshy soil at the river bank which is known to act as sink for the heavy metals hence, were more exposed to higher concentration of the heavy metals for longer period of time whereas the prawns swim actively about and are less exposed to the heavy metal pollution.

\section{Conclusion}

Our study demonstrated, firstly, that the two earthworm species and freshwater prawn bio-accumulated heavy metals; however, earthworms could be a better predictor of heavy metals pollution in limicolous environment owing to the level of heavy metal accumulation in them. Secondly, the synergistic effects of bioaccumulated metals, elicited the production of varying concentrations of antioxidants, among which SOD remains the frontline protective mechanism for cells. Lastly, the RAPD-PCR established that heavy metal accumulation caused mutated changes in the DNA of the earthworms.

\section{Conflicts of interest}

None.

\section{Acknowledgment}

This research did not receive any specific grant from funding agencies in the public, commercial, or not-for-profit sectors.

\section{References}

Abdel-Salam, H.A., Hamdi, S.A.H., 2014. Heavy metals monitoring using commercially important crustaceans and mollusks collected from Egyptian and Saudi Arabia coasts. Anim. Vet. Sci. 2 (3), 49-61.

Abdel-Salam, H.A., Hamdi, S.A.H., 2015. Evaluation of the edible muscles of four species of crustaceans from three regions of Egypt and Saudi Arabia. Glob. Adv. Res. J. Agric. Sci. 4 (2), 105-112.

Abdolahpur, M.F., Safahieh, A., Savari, A., Doraghi, A., 2013. Heavy metal concentration in sediment, benthic, benthopelagic, and pelagic fish species from Musa estuary (Persian Gulf). Environ. Monit. Assess. 185, 215-222.

Andre, J., Charnock, J., Sturzenbaum, S.R., Kille, P., Morgan, A.J., Hodson, M.E., 2009. Metal speciation in field populations of earthworms with multi-generational exposure to metalliferous soils: cell fractionation and high energy synchrotron analysis. Environ. Sci. Technol. 43 (17), 6822-6829.

Association of Analytical Chemist (AOAC), 2000. Official Methods of Analysis of A.O.A.C. International 17th edition. vol. II pp. 920-957 (Gaithen burf, MD, USA, Official method).

Atli, G., Canli, M., 2010. Response of antioxidant system of freshwater fish Oreochromis niloticus to acute and chronic metal $(\mathrm{Cd}, \mathrm{Cu}, \mathrm{Cr}, \mathrm{Zn}, \mathrm{Fe})$ exposures. Ecotoxicol. Environ. Saf. 73, 1884-1889.

Ausubel, F., Brent, R., Kingston, R.E., Moore, D.D., Seidman, J.G., Smith, J.A., Struhl, K. (Eds.), 2002. Short Protocols in Molecular Biology, 5th ed. New York, John Wiley and Sons, Inc.

Azqueta, A., Shaposhinkov, S., Collins, A.R., 2009. DNA oxidation: investigating its key role in environmental mutagenesis with the comet assay. Mutat. Res. 674 (1-2), 101-108.

Cambier, S., Gonzalez, P., Durrieu, G., Bourdineaud, J.P., 2010. Cadmium-induced genotoxicity in zebra fish at environmentally relevant doses. Ecotoxicol. Environ. Saf. 73, 312-319.

Cataldo, J.R., Hidalgo, M.E., Neaman, A., Gaete, H.O., 2011. Use of a molecular biomarker in Eisena foetida to assess copper toxicity in agricultural soil affected in mining activities. J. Soil Sci. Plant Nutr. 11 (3), 57-70.

Dedeke, G.A., Owagboriaye, F.O., Adebambo, A.O., Ademolu, K.O., 2016. Earthworm Metallothionein Production as Biomarker of Heavy Metal Pollution in Abattoir Soil.

Dittbrenner, N., Triebskorn, R., Moser, I., Capowiez, Y., 2010. Physiological and behavioural effects of imidacloprid on two ecologically relevant earthworm species (Lumbricus terrestris and Aporrectodea caliginosa). Ecotoxicology 19, 1567-1573.
Ebenezer, O.D., Kelechi, L.N., Akinniyi, A.O., Modupe, O.A., 2013. Evaluation of the responses of a wetland, tropical earthworm to heavy metal contaminated soil. Int. J. Environ. Monit. Anal. 1 (2), 47-52.

El Assal, F.M., Sabet, S.F., Varjabedian, K.G., Fol, M.F., 2014. Pollution of freshwate Coelatura species (Mollusca: Bivalvia: Unionidae) with heavy metals and its impact on the ecosystem of the River Nile in Egypt. Int. J. Waste Resour. 4, 163. https:// doi.org/10.4172/2252-5211.1000163.

Ellman, G.L., 1959. Tissue sulfhydryl groups. Arch. Biochem. Biophys. 82 (1), 70-77.

Fergusson, R.R., Chance, B., 1955. Substrate specificity of peroxidase. Science. 122 (3167), $466-467$.

Fisker, K.V., Sorensen, J.G., Damgaard, C., Pedersen, K.L., Holmstrup, M., 2011. Genetic adaptation of earthworms to copper pollution: is adaptation associated with fitness costs in Dendrobaena octaedra? Ecotoxicology 20, 563-573.

Galindo, B.A., Troilo, G., Colus, I.M.S., Martinez, C.B.R., Sofia, S.H., 2010. Genotoxic effects of aluminium on the neotropical fish Prochilodus lineatus. Water Air Soil Pollut. 212, 419-428.

Habig, W.H., Pabst, M.J., Jakoby, W.B., 1974. Glutathione S-transferases. The first enzymatic step in mercapturic acid formation. J. Biol. Chem. 249 (22), 7130-7139.

Heidarieh, M., Maragheh, M.G., Shamami, M.A., Behgar, M., Ziaei, F., Akbari, Z., 2013. Evaluate of heavy metal concentration in shrimp (Penaeus semisulcatus) and crab (Portunus pelagicus) with INAA method. SpringerPlus 2, 72-77.

Ilhan, D., Ibrahim, I.O., Guzin, T., Mehmet, S.S., Huseyin, T., 2016. Assessment of cdinduced genotoxic damage in Urtica pilulifera L. using RAPD-PCR analysis. Biotechnol. Biotechnol. Equip. 30 (2), 284-291.

Joseph, K.S., Kafilat, A.B., 2012. Toxicological effects of lead and zinc on antioxidant enzymes activities of post juvenile Clarias gariepinus. Resour. Environ. 2 (1), 21-26.

Kumar, P., Kumar, R., Nagpure, N.S., Nautiyal, P., Kushwaha, B., Nwani, C.D., Lakra, W.S. 2015. In vivo assessment of DNA damage in Cyprinus carpio after exposure to potassium dichromate using RAPD. Turk. J. Vet. Anim. Sci. 39:121-127. https://doi.org/ 10.3906/vet-1210-48.

Li, M., Zhu, Q., Hu, C., Giesy, J.P., Kong, Z., Cui, Y., 2011. Protective effects of eicosapentaenoic acid on genotoxicity and oxidative stress of cyclophosphamide in mice. Environ. Toxicol. 26 (3), 217-223.

Lopez-Lopez, E., Sedeno-Diaz, J.E., Soto, C., Favari, L., 2011. Responses of antioxidant enzymes, lipid peroxidation, and $\mathrm{Na} / \mathrm{K}-\mathrm{ATP}$ ase in liver of the fish Goodea atripinnis exposed to Lake Yuriria water. Fish Physiol. Biochem. 37, 511-522.

Manosathiyadevan, M., Selvisabhanayakam, Divya, V., 2013. Metabolic and antioxidant enzyme activity in hepatopancreas of the adult male freshwater prawn Macrobrachium malcolmsonii (H. Milne Edwards) exposed to Paravanar River pollutants. Int. J. Res. Biosci. 2 (1), 83-91.

Mariappan, M., Karuppasamy, R., 2014. Acute toxicity effect of copper and cadmium in single and binary exposure on mortality rate and behavioural responses of freshwater fish, Cyprinus carpio. Int. J. Curr. Res. 6 (3), 5906-5913.

Marioghae, I.E., 1990. Studies on Fishing Methods, Gears and Marketing of Macrobrachium in Lagos Area. Nigeria Institute for Oceanography and Marine Research (NIOMR), Lagos, Nigeria, p. 20.

Marklund, S., Marklund, G., 1974. Involvement of the superoxide anion radical in the autoxidation of pyrogallol and a convenient assay for superoxide dismutase. Eur J. Biochem. 47 (3), 469-474.

Meshram, L.N., Udawant, S.M., Pawar, S., Mishra, P.S., 2014. Bioaccumulation of heavy metals ( $\mathrm{Zn}, \mathrm{Pb}, \mathrm{Cd}$, and $\mathrm{Ni}$ ) in tissues of Penaeus monodon (Fabricius, 1798) from India. Int. J. Adv. Res. 2 (3), 548-555.

Metcalfe, N.B., Alfonso-Alvarez, C., 2010. Oxidative stress as a life-history constraint: the role of reactive oxygen species in craping phenotypes from conception to death. Funct. Ecol. 24, 984-996.

Mitra, K., Banerjee, R., Ghosh, R., Ray, S.K., 2010. Bioaccumulation pattern of heavy metals in the shrimps of the lower stretch of the river ganga. Mesopotamian J. Mar. Sci. 25 (2), 1-14.

Mohamed, R.L., Fagr, Kh. A, Aly, A.A., Hassan, M.H., Abd El bary, 2012. Fish as bio indicators in aquatic environmental pollution assessment: a case study in Abu-Rawash area, Egypt. World Appl. Sci. J. 19 (2), 265-275.

Morgan, A.J., Turner, M.P., Morgan, J.E., 2002. Morphological plasticity in metalsequestering earthworm chloragocytes: morphometric electron microscopy provides a biomarker of exposure in field populations. Environ. Toxicol. Chem. 21 (3), 610-618.

Moriom, B., Mahuya, S., 2014. Effects of mercury on the activities of antioxidant defences in intestinal macrophages of fresh water teleost Channa punctatus (Bloch 1793). Int J. Fish. Aquat. Stud. 2 (1), 172-179.

Nannoni, F., Protano, G., Riccobono, F., 2011. Uptake and bioaccumulation of heavy elements by two earthworm species from a smelter contaminated area in Northern Kosovo. Soil Biol. Biochem. 43, 2359-2367.

Noel, S., Rath, S.K., 2006. Randomly amplified polymorphic DNA as a tool for genotoxicity: an assessment. Toxicol. Ind. Health 22, 267-275.

Omoigberale, M.O., Ikponmwosa-Eweka, O., 2010. Evaluation of heavy metals of the Palaemonid shrimp Macrobrachium vollenhovenii (Herklots, 1851) in Ovia River, Nigeria. Biosci. Res. Commun. 22 (5), 247-254.

Orebiyi, E.O., Awomeso, A.J., Martins, O., Idowu, A.O., Oguntoke, O., Taiwo, A.M., 2010 Assessment of pollution hazards of shallow well water in Abeokuta and environs. Am. J. Environ. Sci. 6 (1), 50-56.

Otitoloju, A.A., Olagoke, O., 2011. Lipid peroxidation and antioxidant defense enzymes in Clarias gariepinus as useful biomarkers for monitoring exposure to polycyclic aromatic hydrocarbons. Environ. Monit. Assess. 30, 340-346.

Owa, S.O., 1992. Taxonomy and Distribution of Nigerian Earthworms of the Family Eudrilidae and Their Use as Possible Indicators of Soil Properties. (Ph.D. thesis). Obafemi Awolowo University, Ile-Ife, Nigeria. 
Owa, S.O., Dedeke, G.A., Moreyibi, O.H., Morafa, S.O.A., Senjobi, B.A., Aladesida, A.A., 2010 Partitioning of chemical effects on growth performance of the vegetable Amaranthus. Aust. J. Basic Appl. Sci. 4 (8), 3755-3761.

Owagboriaye, F.O., 2014. Earthworm Biomarkers as Tools for Heavy Metal Pollution Assessment in Abattoir Soil. (M.Sc. Thesis). Federal University of Agricultural, Abeokuta, Ogun State. Nigeria.

Pablo, B., Lidia, J.D., Ivan, G.-M., 2013. Predator-induced physiological responses in tadpoles challenged with herbicide pollution. Curr. Zool. 59 (4), 475-484.

Pelosi, C., Toutous, L., Chiron, F., Dubs, F., Hedde, M., Muratet, A., Ponge, J.F., Salmon, S. Makowski, D., 2013. Reduction of pesticide use can increase earthworm populations in wheat crops in a European temperate region. Agric. Ecosyst. Environ. 181, 223-230.

Peranandam, R., Palanisamy, I., Lourclaraj, A.V., Nateson, M., Vimalananthan, A.P., Thangaiyan, S., Perumal, A., Muthaukalingan, K., 2014. TBT effects on development of intersex (ovotestis) in the female freshwater prawn (Macrobrachium rosenbergii). Biomed. Res. Int. 2014, 12 pp, 412619.

Pratviel, G., 2012. Oxidative DNA damage mediated by transition metal ions and their complexes. In: Sigel, Astrid, Sigel, Helmut, Roland, K.O. Sigel (Eds.), Interplay between Metal Ions and Nucleic Acids. Metals Ions in Life Sciences 10. Springer, pp. 201-216 Chapter 7.

Saglam, D., Atli, G., Dogan, Z., Baysoy, E., Gurler, C., Eroglu, A., Canli, M., 2014. Response of the antioxidant system of freshwater fish (Oreochromis niloticus) exposed to metals $(\mathrm{Cd}, \mathrm{Cu})$ in differing hardness. Turk. J. Fish. Aquat. Sci. 14, 43-52.
Seufi, A.M., Ibrahim, S.S., Elmagharby, T.K., Hafez, E.E., 2009. Preventive effect of the flavonoid quercetin on hepatic cancer in rat via oxidant/antioxidant activity: molecular and histological evidences. J. Clin. Cancer Res. 28, 80.

Soundarapandian, P., Premkumar, T., Dinakaran, G.K., 2010. Impact of bioaccumulation of mercury in certain tissues of the marine Sohrimp, Penaeus monodon (Fabricius) from the Uppanar estuary, Cuddalore, Tamilnadu, India. Curr. Res. J. Biol. Sci. 2 (2), 114-117.

Suarez-Serrano, A Alcaraz, C. Ibanez, C. Trobajo, C. Barata, C. 2010. Procambus clarkia as a bioindicator of heavy metal pollution sources in the lower Ebro River and Delta. Ecotoxicol. Environ. Saf. 73 (3), 280-286.

Tarasub, N., Tarasub, C., Ayutthaya, W.D.N., 2011. Protective role of curcumin on cadmium induced nephrotoxicity in rats. J. Environ. Chem. Ecotoxicol. 3 (2), 17-24.

Tumminello, R.A., Fuller-Espie, S.L., 2013. Heat stress induces ROS production and histone phosphorylation in coelomocytes of Eisenia hortensis. Invertebr. Surviv. J. 10, 50-57.

Ubwa, S.T, Atoo, G.H. Offem, J.O. Abah, J., Asemave, K, 2013. Effect of activities at the Gboko abattoir on some physical properties and heavy metals levels of surrounding soil. Int. J. Chem. 5 (1), 49-57.

Valko, M., Morris, H., Shronin, M.T., 2005. Metals, toxicity and oxidative stress. Curr. Med. Chem. 12 (10), 1161-1208.

Zohra, B.S., Nicolas, C., Elise, G., Pierre-Emmanuel, B., Habib, A., Lotfi, A., 2014. First evidence of fish genotoxicity induced by heavy metals from landfill leachates: the advantage of using the RAPD-PCR technique. Ecotoxicol. Environ. Saf. 101, 90-96. 